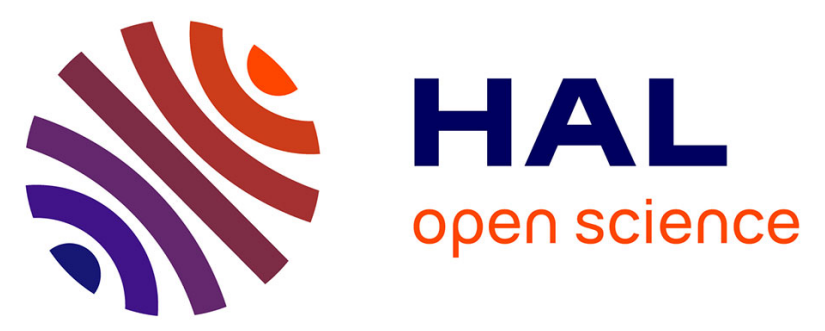

\title{
Genetic Relationships between Measures of Sexual Development, Boar Taint, Health and Aggressiveness in Pigs
}

Séverine Parois, Armelle Prunier, Marie-José Mercat, Nelly Muller, Elodie Merlot, Catherine Larzul

\section{To cite this version:}

Séverine Parois, Armelle Prunier, Marie-José Mercat, Nelly Muller, Elodie Merlot, et al.. Genetic Relationships between Measures of Sexual Development, Boar Taint, Health and Aggressiveness in Pigs. 10. World Congress on Genetics Applied to Livestock Production (WCGALP), Aug 2014, Vancouver, Canada. 2014, Proceedings of the 10th World Congress on Genetics Applied to Livestock Production. hal-01194012

\section{HAL Id: hal-01194012 https://hal.science/hal-01194012}

Submitted on 3 Jun 2020

HAL is a multi-disciplinary open access archive for the deposit and dissemination of scientific research documents, whether they are published or not. The documents may come from teaching and research institutions in France or abroad, or from public or private research centers.
L'archive ouverte pluridisciplinaire HAL, est destinée au dépôt et à la diffusion de documents scientifiques de niveau recherche, publiés ou non, émanant des établissements d'enseignement et de recherche français ou étrangers, des laboratoires publics ou privés. 
Proceedings, $10^{\text {th }}$ World Congress of Genetics Applied to Livestock Production

\title{
Genetic Relationships between Measures of Sexual Development, Boar Taint, Health and Aggressiveness in Pigs
}

\author{
S. Parois ${ }^{*}$, A. Prunier ${ }^{*}$, M.J. Mercat ${ }^{\dagger}$, N. Muller ${ }^{\ddagger}$, E. Merlot ${ }^{*}$, C. Larzul $^{\S}$ \\ *INRA, UMR1348, PEGASE, 35590 Saint-Gilles; ${ }^{\dagger}$ IFIP, 35653 Le Rheu; ${ }^{\ddagger}$ INRA, UETP, 35653 Le Rheu; \\ ${ }^{\S}$ INRA, UMR1313, GABI, 78350 Jouy-en-Josas, France.
}

\begin{abstract}
The aim of the study was to estimate genetic relations between sexual development, boar taint, health and aggressiveness. About 1600 Pietrain type (purebred) or Pietrain $\mathrm{x}$ Large White type (crossbred) boars were raised in a testing station. Blood samples were collected at about $105 \mathrm{~kg}$ liveweight for measuring two sex hormones and two Acute-Phase Proteins (APPs). Animals were slaughtered one week later, measured for boar taint compounds and skin lesions on carcass (LSC), an indicator of aggressiveness.

Heritability was moderate for the $\mathrm{C}$-reactive protein $\left(\mathrm{h}^{2}=0.24\right.$ and $\mathrm{h}^{2}=0.45$, respectively for purebred and crossbred), whereas it was low for the major pig APP $\left(\mathrm{h}^{2}=0.06\right.$ and $\mathrm{h}^{2}=0.05$ ). Heritability of LSC was moderate for both types $\left(h^{2}=0.31\right)$. High genetic correlations between androstenone and estradiol (around 0.85 for both types) and moderate genetic correlations between LSC and testosterone (around 0.45 for both types) were estimated.
\end{abstract}

Keywords: Pubertal development; Acute-Phase Protein; Skin lesions

\section{Introduction}

For pig welfare considerations, the European pig industry is engaged in a voluntary abandonment of surgical castration of male piglets by 2018. Breeding boars appears to be the most promising alternative (de Roest et al. (2009)). However, a condition of this abandonment is to solve problems mostly related to meat quality and aggressiveness. Problems with boar meat are due to the accumulation of three smelling components: $5 \alpha$-androst-16-en-3-one (androstenone), 3-methylindole (skatole) and 2,3benzopyrrole (indole). Additionally, boars have increased aggressiveness, which may impair welfare and carcass quality. In pigs, slaughter age coincides with the attainment of puberty. Sexual development may influence aggressiveness and may be influenced by health status.

Selection to decrease boar taint is possible (Robic et al. (2008)). However, before implementing such a selection, it is necessary to estimate all possible consequences, especially on sexual development, health and welfare.

In the present study, we used the Pietrain type either in pure or in cross breeding with Large White type sows since Pietrain type breed is the predominant terminal sire line used in France.

The aim of the present study was to estimate genetic relationships between sex hormones, boar taint compounds, inflammatory markers and carcass skin lesions.

\section{Materials and Methods}

Animals and management. A total of 749 purebred Pietrain type boars (Pure) and 791 crossed Pietrain $\times$ Large White type boars (Crossed), were raised within the same conditions from post-weaning to slaughter $(110 \mathrm{~kg})$ in a testing station (Le Rheu, France). Boars were housed in groups of 10-12 and fed ad libitum at an electronic singlespace feeder, with pellets of standard composition (net energy $(\mathrm{NE})=9.5 \mathrm{MJ} / \mathrm{kg}$; total nitrogenous matter $=$ $163 \mathrm{~g} / \mathrm{kg}$; digestible lysine content $=0.94 \mathrm{~g} / \mathrm{MJ} \mathrm{NE}$; digestible tryptophan content $=1.7 \mathrm{~g} / \mathrm{kg}$ ).

Measures. A blood sample was collected in EDTA tubes by direct puncture from the external jugular vein, at approximately $105 \mathrm{~kg}$ liveweight. Blood samples were centrifuged and plasma was stored at $-20^{\circ} \mathrm{C}$ until analysis of sex hormones (testosterone and $17 \beta$-estradiol) and acutephase proteins (APPs) (C-reactive protein (CRP) and major APP of Pigs (pigMAP)). Sex hormones were measured using radioimmunoassay kits (testosterone: Immunotech, Prague, Czech Republic; estradiol: Orion Diagnostica, Espoo, Finland); whereas APPs were measured using ELISA kits (CRP: Genway Biotech, San Diego, California; pigMAP: PigCHAMP, Segovia, Spain). At slaughter, skin lesions were counted on both sides of carcasses without heads and legs. A piece of backfat was sampled on the carcass and frozen at $-20^{\circ} \mathrm{C}$. Boar taint compounds (androstenone, skatole and indole) were measured by HPLC using liquid fat (Batorek et al. (2012)). Pedigree information was available for all boars up to 5 generations. Pure bred and crossbred were offspring from the same sires.

Statistical analyses. Statistical analyses were performed separately for the two genetic types. After preliminary estimates of sex hormones, boar taint compounds and skin lesions were normalized by logarithmic transformation, APPs were normalized by square root transformation. Limit of sensitivity of the assay was $0.24 \mu \mathrm{g} / \mathrm{g}$ for androstenone, $0.03 \mu \mathrm{g} / \mathrm{g}$ for skatole and indole, $0.2 \mathrm{ng} / \mathrm{mL}$ for testosterone and $2.5 \mathrm{pg} / \mathrm{mL}$ for estradiol. Therefore, for samples below the limit of detection, concentration was fixed to that threshold. This procedure overestimates means of the variables.

First analyses were done with the Proc Mixed procedure of the software SAS/STAT ${ }^{\circledR} 9.4$ (SAS (2013)) to define effects retained in the final model. Model of analysis included the batch, date of sampling and weight at measure, when relevant $(\mathrm{P}<0.10)$. 
Heritabilities and genetic correlations were estimated using the restricted maximum likelihood methodology applied to a multiple trait animal model, with the VCE6 software (Neumaier \& Groeneveld (1998); Groeneveld et al. (2010)). As analyses included 4 variables, heritability and genetic correlations were estimated several times. For parameters, we present the average of values, and for standard-error, the maximal value.

\section{Results and Discussion}

Means of transformed traits are shown in Table 1. Mean values for sex hormones, boar taint compounds and CRP correspond to what was expected for boars (Clapperton et al. (2009); Grindflek et al. (2011)). Pearson's coefficients of phenotypic correlation are shown in Table 2 and estimates of genetic parameters are shown in Table3.

Table 1. Numbers, means and standard errors (SD) of transformed variables for PURE bred and CROSS bred boars.

\begin{tabular}{|c|c|c|c|c|c|c|}
\hline & \multicolumn{3}{|c|}{ PURE } & \multicolumn{3}{|c|}{ CROSS } \\
\hline Trait $^{1}$ & $\mathrm{~N}$ & Mean & SE & $\mathrm{N}$ & Mean & SD \\
\hline TES & 672 & 0.15 & 0.66 & 757 & 0.27 & 0.64 \\
\hline E2 & 672 & 1.01 & 0.33 & 755 & 1.09 & 0.43 \\
\hline AND & 654 & -1.06 & 0.60 & 757 & -0.94 & 0.62 \\
\hline SKA & 654 & -3.31 & 0.43 & 757 & -3.15 & 0.57 \\
\hline IND & 654 & -3.38 & 0.37 & 757 & -3.42 & 0.36 \\
\hline CRP & 672 & 9.01 & 2.70 & 757 & 8.08 & 2.64 \\
\hline PM & 672 & 30.5 & 11.9 & 757 & 29.4 & 11.3 \\
\hline LSC & 654 & 3.45 & 0.90 & 754 & 3.91 & 0.99 \\
\hline & & & & $\begin{array}{l}(\log ) \\
\text { IND }\end{array}$ & & $\begin{array}{r}\text { AND } \\
\text { CRP } \\
\text { _Skin }\end{array}$ \\
\hline
\end{tabular}

Table 2. Pearson's coefficients of correlation on residual of transformed variables ${ }^{1}$ for PURE bred and CROSS bred boars.

\begin{tabular}{lrrrrrrrr}
\hline Trait $^{2}$ & TES & E2 & AND & SKA & IND & CRP & PM & LSC \\
\hline TES & & $\mathbf{0 . 2 6}$ & $\mathbf{0 . 2 4}$ & $\mathbf{0 . 1 0}$ & 0.07 & $\mathbf{- 0 . 1 1}$ & -0.002 & 0.07 \\
E2 & $\mathbf{0 . 3 8}$ & & $\mathbf{0 . 5 3}$ & $\mathbf{0 . 1 4}$ & $\mathbf{0 . 0 8}$ & 0.008 & 0.03 & $\mathbf{0 . 0 9}$ \\
AND & $\mathbf{0 . 2 3}$ & $\mathbf{0 . 5 9}$ & & $\mathbf{0 . 1 3}$ & $\mathbf{0 . 1 1}$ & $\mathbf{- 0 . 1 2}$ & -0.03 & $\mathbf{0 . 0 8}$ \\
SKA & $\mathbf{0 . 1 2}$ & $\mathbf{0 . 1 7}$ & $\mathbf{0 . 1 6}$ & & $\mathbf{0 . 3 5}$ & -0.05 & -0.03 & 0.03 \\
IND & 0.01 & $\mathbf{0 . 0 8}$ & $\mathbf{0 . 0 8}$ & $\mathbf{0 . 2 6}$ & & -0.02 & 0.008 & -0.07 \\
CRP & -0.05 & -0.06 & $\mathbf{- 0 . 0 7}$ & $\mathbf{- 0 . 1 2}$ & -0.06 & & $\mathbf{- 0 . 1 5}$ & $\mathbf{- 0 . 1 4}$ \\
PM & -0.06 & -0.01 & -0.01 & $\mathbf{- 0 . 0 7}$ & -0.05 & $\mathbf{0 . 2 2}$ & & -0.02 \\
LSC & 0.03 & 0.04 & 0.06 & 0.03 & 0.04 & -0.06 & -0.02 & \\
\hline
\end{tabular}

${ }^{1}$ Values for PURE above diagonal and for CROSS below diagonal.

Within the table values in bold have a P-value $<0.05$.

${ }^{2}$ Traits: cf. Table 1 .

Table 3. Estimates of genetic parameters ${ }^{1}$ for PURE bred and CROSS bred boars.

\begin{tabular}{lrrrrrrrr}
\hline \multicolumn{7}{c}{ PURE } \\
\hline Trait $^{2}$ & TES & E2 & AND & SKA & IND & CRP & PM & LSC \\
\hline TES & 0.19 & 0.85 & 0.75 & 0.71 & 0.16 & -0.13 & 0.09 & 0.43 \\
E2 & 0.33 & 0.20 & 0.83 & 0.52 & 0.17 & -0.05 & -0.38 & 0.46 \\
AND & 0.24 & 0.12 & 0.64 & 0.61 & 0.22 & -0.11 & -0.49 & -0.06 \\
SKA & 0.16 & 0.14 & 0.10 & 0.37 & 0.40 & -0.02 & -0.12 & 0.05 \\
IND & 0.12 & 0.16 & 0.11 & 0.11 & 0.87 & 0.07 & 0.15 & -0.30 \\
\hline
\end{tabular}

\begin{tabular}{lrrrrrrrrr}
\hline CRP & 0.14 & 0.16 & 0.17 & 0.09 & 0.09 & 0.24 & 0.13 & -0.31 \\
PM & 0.39 & 0.40 & 0.33 & 0.36 & 0.32 & 0.42 & 0.06 & -0.04 \\
LSC & 0.21 & 0.27 & 0.10 & 0.20 & 0.15 & 0.21 & 0.15 & 0.31 \\
\hline \hline \multicolumn{7}{c}{ CROSS } \\
\hline Trait $^{2}$ & TES & E2 & AND & SKA & IND & CRP & PM & LSC \\
\hline TES & 0.29 & 0.67 & 0.32 & 0.31 & 0.08 & -0.20 & -0.70 & 0.53 \\
E2 & 0.19 & 0.16 & 0.95 & 0.41 & -0.37 & -0.07 & -0.12 & 0.006 \\
AND & 0.15 & 0.08 & 0.70 & 0.36 & 0.04 & -0.22 & 0.22 & -0.17 \\
SKA & 0.14 & 0.20 & 0.10 & 0.24 & 0.27 & -0.18 & -0.01 & 0.03 \\
IND & 0.22 & 0.42 & 0.20 & 0.31 & 0.09 & -0.01 & -0.93 & 0.001 \\
Crp & 0.11 & 0.14 & 0.12 & 0.10 & 0.13 & 0.45 & -0.15 & 0.006 \\
PM & 0.32 & 0.50 & 0.39 & 0.42 & 0.18 & 0.42 & 0.05 & -0.22 \\
LSC & 0.19 & 0.19 & 0.11 & 0.27 & 0.34 & 0.07 & 0.38 & 0.31 \\
\hline
\end{tabular}

${ }^{1}$ Heritabilities on diagonal, genetic correlations above diagonal and standard-error of genetic correlation below diagonal.

Standard-errors for heritabilities were between 0.06 and 0.10 both for purebred and crossbred boars.

${ }^{2}$ Traits: cf. Table 1.

\section{Heritabilities of traits}

Heritabilities for boar taint compounds were similar to those reported by Grindfleck ((2011)). Androstenone had a high heritability $\left(\mathrm{h}^{2}=0.64\right.$ and 0.70 , respectively for purebred and crossbred boars) whereas skatole had a moderate heritability $\left(\mathrm{h}^{2}=0.37\right.$ and 0.24 , respectively for purebred and crossbred boars), which agrees well with many observations showing that skatole depends more on the environment and androstenone on the genotype (Zamaratskaia \& Squires (2009)). Unexpectedly, results for indole were very different between purebred and crossbred boars. It may be explained by the fact that nearly $90 \%$ of measures from Pietrain $\mathrm{x}$ Large White type boars were under the threshold of detection. In Pietrain boars, Mathur et al. ((2013)) reported a much lower heritability for indole $\left(\mathrm{h}^{2}=0.29\right)$.

Both testosterone and estradiol had moderate heritabilities $\left(\mathrm{h}^{2}=0.19\right.$ and 0.29 for testosterone and $\mathrm{h}^{2}=0.20$ and 0.16 for estradiol, respectively for purebred and crossbred boars). These results were similar to previous estimates in pig (Grindflek et al. (2011)).

CRP heritability for purebred was similar to that estimated in previous studies $\left(\mathrm{h}^{2}=0.24\right)$ (Clapperton et al. (2009); Flori et al. (2011)) whereas it was higher in crossbred boars $\left(\mathrm{h}^{2}=0.45\right)$. Heritability for pigMAP was very low $\left(\mathrm{h}^{2}=0.06\right.$ and 0.05 , respectively for purebred and crossbred boars) suggesting a more profound influence of the environment on this trait. No previous estimation of pigMAP heritability has been reported in literature. Heritability of carcass skin lesions was moderate and similar for both purebred and crossbred boars $\left(\mathrm{h}^{2}=0.31\right)$.

\section{Correlations between sex hormones and boar taint}

Phenotypic correlations between testosterone, estradiol and androstenone were moderately to highly positive ( 0.23 to 0.59 ) in both types of pigs and higher than correlations between sex hormones and skatole $(0.10$ to 0.17$)$. This was expected since sex hormones and androstenone are produced by the testes and hence depend on common mecha- 
nisms of regulation whereas skatole is produced in the gut. However, both androstenone and skatole depend on sexual development of boar (Zamaratskaia \& Squires (2009)).

We estimated very high genetic correlations between androstenone and estradiol ( 0.83 and 0.95 , respectively for purebred and crossbred boars), and very high or moderate genetic correlations between androstenone and testosterone, respectively for purebred and crossbred boars $(0.75$ and 0.32 ). The difference between purebred and crossbred boars is consistent with a weaker genetic correlation between testosterone and estradiol for the latter. Because of common mechanisms of production in the testes, accumulation of androstenone in backfat is linked to the sexual development of boar (Allrich et al. (1983)). Therefore, these high correlations were expected and confirmed genetic correlations previously reported between these traits in Duroc and Landrace breeds (Grindflek et al. (2011)).

As skatole and androstenone are moderately to highly related, positive genetic correlations were also observed between sex hormones and skatole $(0.71$ and 0.52 for testosterone and estradiol for purebred; and 0.31 and 0.41 for crossbred boars). Weaker correlations for crossbred boars might be related to the lower genetic correlation between androstenone and skatole estimated in crossbred boars.

Genetic correlations between androstenone and skatole were moderate to high, according to the genetic type ( 0.61 for purebred and 0.36 for crossbred boars). It has been shown that androstenone has an antagonistic action on skatole degradation by the liver (Doran et al. (2002)). Therefore, positive correlation between the two variables was expected.

Genetic correlations between testosterone and estradiol were high $(0.85$ and 0.67 , respectively for purebred and crossed bred). This result was expected because of common mechanisms of control regarding testicular activity.

\section{Correlations between sexual development traits, skin lesions and APPs}

Phenotypic correlations were relatively low in both genetic types.

Because of the very low heritability of pigMAP, the genetic correlations between this variable and others must be interpreted cautiously. More data are necessary to obtain more precise estimates for genetic correlations between pigMAP and other traits. CRP was genetically negatively correlated with traits of boar taint and sex hormones.

We estimated moderate genetic correlations between carcass skin lesions and testosterone (0.43 and 0.53 , respectively for purebred and crossbred boars). Skin lesion number is an indicator of individual aggressiveness during the post-mixing period (Turner et al. (2006)). Genetic correlations confirmed that aggressive behaviors are associated to development of puberty (Montoya et al. (2012)).

\section{Conclusion}

The two main issues for breeding boars are boar taint occurrence in carcass and aggressive behaviors of boars. Considering the genetic correlations estimated, it would be possible to decrease the occurrence of boar taint and limit aggressive behaviors in boar from Pietrain breed by selecting on estradiol level just before slaughter and hence delay puberty. A direct selection on androstenone would also delay puberty but would have a lower incidence on aggressive behaviors. Both selections would have very low consequences on inflammatory responses.

\section{Acknowledgements}

Authors are extremely grateful to the personnel of the testing station for measures done at the station and at the slaughterhouse, as well as S. Jaguelin F. Thomas and R. Comte from PEGASE for laboratory measures. They thank C. Hassenfratz and A. Varenne for their contribution in setting up and monitoring the experiment.

This study has been done as part of the program UtOpIGe, carried out by INRA, IFIP, SYSAAF, Novogen, and Bioporc pig breeding companies (ADN, Choice Genetics France, Gène+, Nucleus). This program received financial support from ANR (ANR-10-GENOM_BTV-015 UtOpIGe), FranceAgrimer, InaPorc, and INRA (Metaprogram GISA Healthygrowth and Genetic Animal division).

\section{Literature Cited}

Allrich, R.D., Christenson, R.K., Ford, J.J. et al. (1983). Biol. Reprod., 28:902-909.

Batorek, N., Škrlep, M., Prunier, A. et al. (2012). J. Anim. Sci., 90:4593-4603.

Clapperton, M., Diack, A.B., Matika, O. et al. (2009). Genet. Sel. Evol., 41:1-11.

de Roest, K., Montanari, C., Fowler, T. et al. (2009). Animal, 3:1522-1531.

Doran, E., Whittington, F.W., Wood, J.D. et al. (2002). ChemBiol. Interact., 140:81-92.

Flori, L., Gao, Y., Laloë, D. et al. (2011). PLoS One, 6:e22717.

Grindflek, E., Meuwissen, T.H.E., Aasmundstad, T. et al. (2011). J. Anim. Sci., 89:680-692.

Groeneveld, E., Kovac, M., and Mielenz, N. (2010). 1-125.

Mathur, P.K., ten Napel, J., Crump, R.E. et al. (2013). J. Anim. Sci., 91:4080-4089.

Montoya, E.R., Terburg, D., Bos, P.A. et al. (2012). Motiv. Emotion, 36:65-73.

Neumaier, A., and Groeneveld, E. (1998). Gen. Sel. Evol., 30:326.

Robic, A., Larzul, C., and Bonneau, M. (2008). Genet. Sel. Evol., 40:129-143.

SAS. (2013). "Version 9.4, SAS Inst. Inc., Cary, NC."

Turner, S.P., Farnworth, M.J., White, I.M.S. et al. (2006). Appl. Anim. Behav. Sci., 96:245-259.

Zamaratskaia, G., and Squires, E.J. (2009). Animal, 3:1508-1521. 